\title{
COMPUTER SIMULATION OF THE STEADY-STATE FLOW SYSTEM OF THE TERTIARY LIMESTONE (FLORIDAN) AQUIFER SYSTEM IN EAST-CENTRAL FLORIDA
}

U.S. GEOLOGICAL SURVEY

WATER-RESOURCES INVESTIGATIONS OPEN-FILE REPORT 81-681

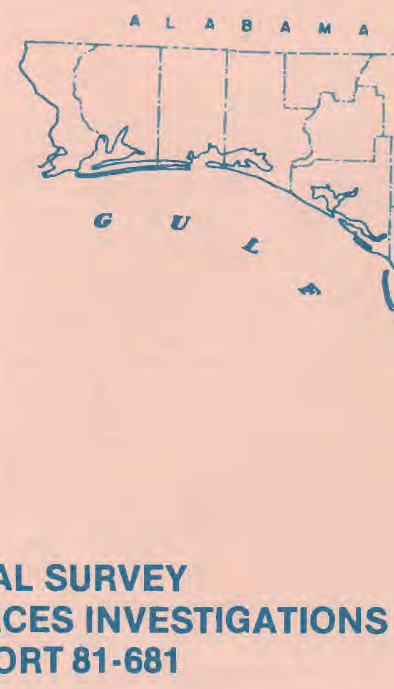



UNITED STATES

DEPARTMENT OF THE INTERIOR

GEOLOGICAL SURVEY

COMPUTER SIMULATION OF THE STEADY-STATE FLOW SYSTEM OF THE

TERTIARY LIMESTONE (FLORIDAN) AQUIFER SYSTEM IN EAST-CENTRAL FLORIDA

By C. H. Tibbals

U.S. GEOLOGICAL SURVEY

WATER-RESOURCES INVESTIGATIONS

OPEN-FILE REPORT $81-681$

Ta11ahassee, Florida

1981 


\section{UNITED STATES DEPARTMENT OF THE INTERIOR \\ JAMES G. WATT, Secretary \\ GEOLOGICAL SURVEY \\ Da1las L. Peck, Director}

For additional information write to:

U.S. Geologica1 Survey

Suite F-240

325 John Knox Road

Tallahassee, FL 32303 
Abstract--_-_-_- 1

Introduction-- 3

Description of the area--_- 3

Topography-- 3

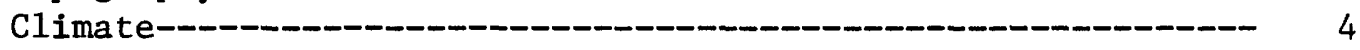

Drainage---_-_- 4

Hydrogeologic setting-_-_- 6

Surficial aquifer-_-_-_-_-_-_ 6

Tertiary limestone (Floridan) aquifer system-- 7

Potentiometric surface-- 7

Digital computer mode1-_- 8

Boundary conditions-_-_-_-_- 9

Hydrogeologic input data- 11

Hydraulic head- 12

Storage coefficient--_-_-_-_ 12

Transmissivity--_-_-_-_-- 12

Leakance-- 13

Head-controlled flux (HCF) boundary conditions------- 14

Model calibration--_-_-_- 15

Parameter sensitivity analysis-_- 21

Summary of the predevelopment flow system-- 21

References- 30

\section{ILLUSTRATIONS}

Page

Figure 1. Map showing location of study area and major surface drainage basins-_- In pocket

2. Graphs of rainfall at Palatka, Orlando, and Avon Park---_-_-_-_-

3. Sketch showing geologic units, hydrogeologic units, and equivalent layers used in computer mode1---- In pocket 4-10. Maps showing:

4. Potentiometric surface of the upper Floridan aquifer prior to development, spring discharge, and model boundary conditions for the upper Floridan (model layer 2)------- In pocket

5. Finite-difference grid superimposed on modeled area--

6. Locations of selected aquifer test sites and probable ranges of transmissivity of the upper Floridan aquifer (model layer 2) based on model calibration-_-_-_-_-_-- In pocket

7. Estimated values of transmissivity of the lower Floridan aquifer (model layer 1) based on model calibration-_-_-_-_-_-- In pocket 
Figure 4-10. Maps showing:--Continued

8. Rates of recharge and discharge to and from the upper Floridan aquifer (model layer 2) through the upper confining bed based on model calibration---- In pocket

9. Difference between observed and computed potentiometric surface of the upper Floridan aquifer (model layer 2) In pocket

10. Difference between estimated and computed potentiometric surface of the lower Floridan aquifer (model layer 1 )

In pocket

\section{TABLES}

Table 1. Model input data--

2. Flow of springs and at other head-controlled flux nodes in the upper Floridan aquifer (model 1ayer 2)

3. Effect of varying transmissivity and leakance on average error per node for the upper and lower Floridan aquifer (model layers 1 and 2) and on key spring discharge and model boundary flows-- 
For use of readers who prefer to use metric units, conversion factors for terms used in this report are listed below:

\section{$\underline{\text { Mu1tip1y }}$}

foot ( $f t$ )

foot squared per day $\left(\mathrm{ft}^{2} / \mathrm{d}\right)$

cubic foot per second $\left(\mathrm{ft}^{3} / \mathrm{s}\right)$

ga11on per minute (ga1/min) million gallon per day (Mgal/d)

inch (in)

inch per year (in/yr)

mile (mi)

square mile $\left(\mathrm{mi}^{2}\right)$
By

0.3048

0.0929

0.02832

0.06309

0.0438

25.40

25.40

1.609

2.590
To obtain

$$
\begin{aligned}
& \text { meter (m) } \\
& \text { meter squared per day } \\
& \left(\mathrm{m}^{2} / \mathrm{d}\right) \\
& \text { cubic meter per second } \\
& \left(\mathrm{m}^{3} / \mathrm{s}\right) \\
& 1 \text { iter per second (L/s) } \\
& \text { cubic meter per second } \\
& \left(\mathrm{m}^{3} / \mathrm{s}\right) \\
& \text { millimeter (mm) } \\
& \text { millimeter per year } \\
& (\mathrm{mm} / \mathrm{yr}) \\
& \text { kilometer (km) } \\
& \text { square kilometer }\left(\mathrm{km}^{2}\right)
\end{aligned}
$$

Temperature in degrees Fahrenheit $\left({ }^{\circ} \mathrm{F}\right)$ can be converted to degrees Celsius $\left({ }^{\circ} \mathrm{C}\right)$ as follows:

$$
{ }^{\circ} \mathrm{F}=1.8^{\circ}+32
$$

National Geodetic Vertical Datum of 1929 (NGVD of 1929): A geodetic datum derived from a general adjustment of the first-order level nets of both the United States and Canada, called NGVD of 1929, is referred to as sea level in this report. 
$$
\text { . }
$$ 
COMPUTER SIMULATION OF THE STEADY-STATE FLOW SYSTEM OF THE

TERTIARY LIMESTONE (FLORIDAN) AQUIFER SYSTEM IN EAST-CENTRAL FLORIDA

By C. H. Tibbals

ABSTRACT

The predevelopment steady-state ground-water flow system for the Tertiary limestone (Floridan) aquifer system in east-central Florida is simulated by means of a digital computer model. The modeled area covers about 13,700 square miles. The configuration of the model is that of a three-layered system; the lower Floridan aquifer, the upper Floridan aquifer, and the surficial aquifer.

The model results indicate that about 1,900 cubic feet per second recharges the Floridan aquifer as downward leakage from the surficial aquifer. The average recharge rate where recharge actually occurs (approximately 6,550 square miles) is about 4 inches per year. The maximum recharge rate is about 14 inches per year. An additiona 120 cubic feet per second is recharged to the modeled area of the Floridan aquifer by means of lateral boundary inflow along the northeast boundary.

The Floridan aquifer system, as simulated, discharges about 1,300 cubic feet per second as springflow, 540 cubic feet per second as diffuse upward leakage to the surficial aquifer in an area of approximately 7,150 square miles and 80 cubic feet per second as lateral boundary outflow to the southwest and to the east.

The average transmissivity of the upper Floridan aquifer, as simulated, is about 120,000 feet squared per day while that for the lower Floridan is about 60,000 feet squared per day. Inflow and outflow for the upper Floridan can be summarized as follows:

1. The highest rates of recharge to the Floridan take place in four areas; the west flank of the Volusia County "high," the PutnamAlachua County "high," the potentiometric ridge area of mid-Polk and Highlands Counties, and the northeast flank of the central Florida potentiometric "high" in Lake and Orange Counties and extending into east Marion County.

2. Most discharge from the upper Floridan is in the form of point discharge (about 69 percent of the tota1) to known springs and upward leakage to streams located within 25 miles of recharge areas. 
3. The highest rates of diffuse upward leakage from the upper Floridan (about 28 percent of total discharge) occur near areas where the downward leakage rates are also high. Thus, it is inferred that thin or permeable confining beds are common to the areas of high downward leakage and to the nearby areas of high upward leakage.

4. Lateral boundary outflow from the upper Floridan aquifer (principally occurring along the Atlantic coast) is relatively sma11 and consists of about 4 percent of the total discharge. Lateral flow to the south is about 0.7 percent of the total discharge.

5. Interchange between the upper and lower Floridan aquifer layers is very small compared to the flow within the upper Floridan.

6. The model-derived transmissivities are considered to have more regional significance than transmissivity values derived from individual aquifer tests.

In summary, the hydraulics of the Floridan aquifer system under predevelopment conditions involve mostly recharge to the upper Floridan (via leakage from the surficial aquifer), lateral movement through the upper Floridan for short distances, and discharge via springs and upward leakage to streams. Relatively small amounts of discharge occur along the coast and small amounts move into and out of the underlying lower Floridan. This natural hydraulic equilibrium implies a vigorous flow system locally in the upper Floridan and, except in west Orange County and southeast Lake County, a relatively sluggish flow system in the lower Floridan. 


\section{INTRODUCTION}

The Tertiary limestone (Floridan) aquifer is one of the major sources of ground-water supplies in the southeast United States. Over 3 billion gallons of water are pumped daily from the aquifer system making it the major source of municipal, industrial, and agricultural water supply in large parts of Florida and Georgia, and small parts of Alabama and South Carolina. In Florida, the Floridan aquifer is essentially the equivalent of the Tertiary limestone aquifer system.

The purpose of this interim report is to very briefly document and present the results obtained thus far of a computer model of steadystate, predevelopment ground-water flow in the Floridan aquifer in eastcentral Florida.

The study on which this interim report is derived is one of five substudies that are part of a more comprehensive project to study the entire Tertiary limestone aquifer system. That study has overall objectives that include: (1) a complete description of the hydrogeologic framework and geochemistry of the limestone aquifer system, (2) definition of the regional flow system, and (3) assessment of the effects of large withdrawals of ground water and the injection of wastes into the aquifer.

Specifically, the overall objective of this substudy is to provide for the east-central Florida area, an overall description of the limestone aquifer and a computer simulation of the ground-water flow system.

\section{DESCRIPTION OF THE AREA}

The modeled study area (fig. 1, in pocket), hereinafter referred to as the study area, consists of about $13,700 \mathrm{mi}^{2}$ and includes all or parts of the counties of Alachua, Bradford, Clay, St. Johns, Putnam, Marion, Flagler, Lake, Volusia, Orange, Seminole, Brevard, Polk, Osceola, Highlands, Okeechobee, Indian River, Glades, and St. Lucie.

The principal industries are tourism, agriculture, space research, and light manufacturing. Agricultural products include citrus products, cattle, vegetables, ornamental plants, poultry, timber, and pulpwood.

\section{Topography}

The topography ranges from steeply rolling highlands to flat, swampy lowlands. The steeply rolling highlands are generally at altitudes that range from 100 feet to more than 250 feet above sea level and occur mainly in the northwest and north-central parts of the study area and along the southwest border. In the north-central and south-central parts, the topography is generally moderately rolling to flat and 
altitudes are generally between 35 and 100 feet above sea level. Along the coastal areas and along the St. Johns River, altitudes are generally less than 35 feet above sea level and, except for the coastal dune ridges, the terrain is generally flat and swampy.

\section{$\underline{\text { Climate }}$}

The climate of the area is classified as subtropical humid and is characterized by long, warm, relatively wet summers and mild, relatively dry winters. The average annual air temperature ranges from $69^{\circ} \mathrm{F}$ in the north to about $73^{\circ} \mathrm{F}$ in the south. Most years have a few days of freezing temperatures, but the minimum daily temperature rarely falls below $20^{\circ} \mathrm{F}$. The maximum temperature frequently exceeds $90^{\circ} \mathrm{F}$ but only occasionally exceeds $100^{\circ} \mathrm{F}$. Rainfall is unevenly distributed during the year. About 55 percent of the annual rainfall occurs during four summer months, June, July, August, and September (fig. 2). In addition to the uneven temporal distribution of the rainfall, it can also be unevenly distributed throughout the area at any given time, especially during the summer. This is because most of the summer rainfall is derived from local showers or thunderstorms that occur in a generally random manner. The summer rainfall can be substantially augmented by tropical storms and hurricanes that pass through or near the Florida peninsula from time to time.

Winter rainfall generally results from cold fronta1-type air masses moving from north to south through the area causing the warm resident air masses to lose their moisture, almost always in the form of rain. Winter rainfall generally occurs over wide areas and thus is not as spotty as summer rainfall. The average annual rainfall ranges from about 55 inches in the north and south to about 52 inches in the centra1 study area.

\section{Drainage}

The area is drained in the north and southeast by the northwardflowing St. Johns River and its major tributary, the Oklawaha River (fig. 1, in pocket). The southwest part of the study area is drained by the southward-flowing Kissimmee River and its tributaries. Parts of the extreme west border of the area are drained by the Withlacoochee River and the Peace River. The extreme east border drains into the Coastal Basin. Runoff (unaugmented by sewage, springflow or irrigation return flow) to streams ranges from virtually nil in the steeply rolling sand hills to as much as 18 to $20 \mathrm{in} / \mathrm{yr}$ in the areas where the surface drainage system is well developed (Lichtler, 1972, p. 9). 
EXPLANATION
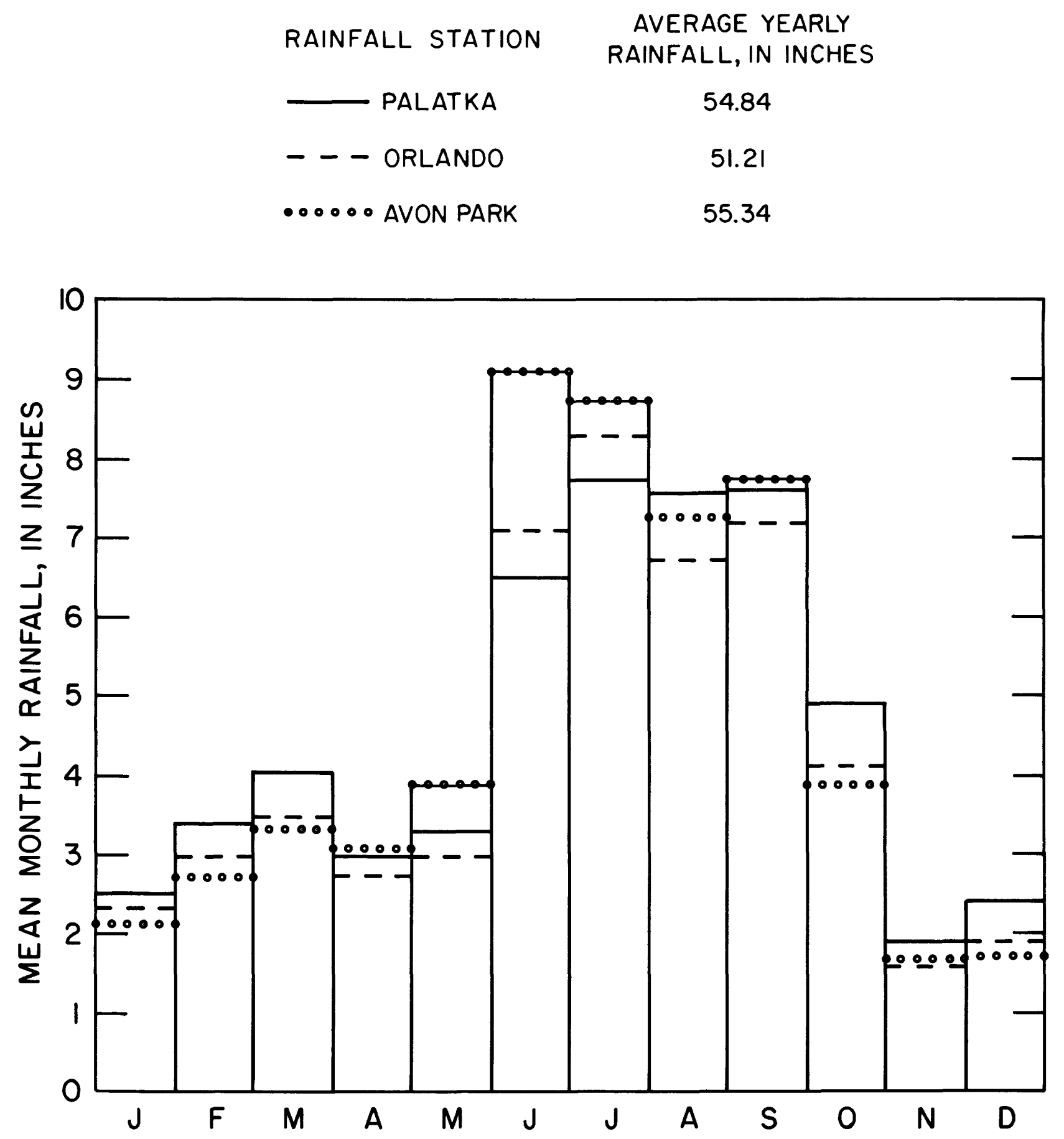

Fiqure 2.--Rainfall at Palatka, Orlando, and Avon Park (National Oceanographic and Atmospheric Administration). 
The geology of the study area has been described by many investigators including Matson and Sanford (1913), Applin and Applin (1944), Cooke (1939 and 1945), Puri and Vernon (1949), Stringfield (1966), Vernon (1951 and 1959), and White (1958 and 1970). A very brief summary of the hydrogeology is presented from the findings of those previous investigators plus the preliminary findings of Miller (1981).

Figure 3 (in pocket) presents a generalized description of the geologic units and shows their relationship to the principal hydrogeologic units (aquifers and confining beds) and equivalent layers in the digital computer model. The aquifers and confining beds are described later in this section of the report.

Geologic structure such as joints or faults can be an important control on the Floridan aquifer ground-water flow system in east-central Florida. The occurrence of Floridan aquifer springs are perhaps, in some instances, the result of joints or faults. The trial-and-error process of model calibration identified several areas where it was necessary to use relatively low values of aquifer transmissivity or high values for confining bed leakance in order to achieve calibration. Several of these areas are coincident with the mapped locations of faults (Miller, 1981). The two main areas are: along the upper Kissimmee River and along the middle and lower reaches of the St. Johns River.

\section{Surficial Aquifer}

The uppermost water-bearing formation is the surficial aquifer which consists of fine to medium-fine quartz sands throughout most of the area. In some coastal areas, the surficial aquifer also consists of cemented shell that forms a coquina. The water table in the surficial aquifer is unconfined. The water table is at or near land surface in many of the swampy lowlands throughout most of the year but can be many tens of feet below land surface in the steeply rolling highlands. At some depth below the water table, the sands generally grade into less permeable clayey or silty sands, that act as a confining bed for the underlying limestones that comprise the Floridan aquifer system.

The surficial aquifer is recharged by local rainfall, irrigation, septic tank effluent, sewage holding-pond effluent, and, in areas where the potentiometric surface of the Floridan aquifer is above the water table, by upward leakage from the Floridan through the confining beds. Water leaves the surficial aquifer by seepage to lakes, ditches, and streams; by evapotranspiration where the water table is near land surface; by pumpage; and, where the potentiometric surface of the Floridan aquifer is below the water table, by downward leakage to the Floridan. 
In terms of the potable water supply of the area, except for the coastal areas, the most important function of the surficial aquifer is to store water, some of which recharges the Floridan aquifer. Except for the coastal areas, the surficial aquifer is little used as a source of water because, relative to the Floridan aquifer, its permeability is low and results in relatively low yields to wells. Also, water from the surficial aquifer of en contains objectionable concentrations of dissolved iron and is sometimes highly colored.

\section{Tertiary Limestone (Floridan) Aquifer System}

In the study area, the Tertiary limestone aquifer system is synonymous with the Floridan aquifer, an approximately 2,000-foot-thick sequence of limestone and dolomitic limestone. The top of the Floridan as used in this report is characterized by the first vertically persistent occurrence of consolidated carbonate rocks. The base of the aquifer (top of the sub-Floridan confining unit) is defined as the first vertically persistent anhydrite beds or, in their absence, the top of the transition of the generally permeable carbonate sequence to the much less permeable gypsiferous and anhydritic carbonate beds of chalk.

The overlying confining unit generally consists of silty or clayey sand and sandy clay that, where present, extends from the base of the surficial aquifer to the top of the Floridan.

The Floridan aquifer is recharged by downward leakage from the surficial aquifer in areas where the water table is above the potentiometric surface of the Floridan and where the overlying confining beds are semipermeable, thin, or breached by sinkholes. Discharge from the Floridan prior to development was by springflow and by upward leakage to the surficial aquifer in areas where the potentiometric surface of the Floridan is above the water table.

In the central and west-central parts of study area, the Floridan is known to have two main water-producing zones separated by a less permeable zone (fig. 3, in pocket). The materials that comprise these zones are essentially the same, therefore this zonation is primarily a distinction between the relative permeabilities of the zones. For the purposes of computer modeling, these zones are held to exist throughout the study area. Preliminary findings by Miller (1981) tend to confirm the regionalization of the zone of low permeability.

\section{Potentiometric Surface}

Figure 4 (in pocket) shows the estimated regional configuration of the potentiometric surface of the upper permeable zone of the Floridan aquifer in the study area prior to ground-water development and is adapted from a multistate potentiometric map of the entire Tertiary limestone aquifer (Johnston and others, 1980). This map is a composite 
of many other maps: recent potentiometric surface maps in areas where pumping has been light; and older maps or modifications of them where ground-water development has been extensive. The map is intended to show the best estimate that can be made with available data of the configuration of the "average" potentiometric surface as it existed prior to development.

The regional flow of ground water in the Floridan aquifer is from areas of high altitude of the potentiometric surface to areas of low altitude, and from areas of recharge to areas of discharge. In the south part of the study area, flow is generally from the southwest to the northeast toward the Atlantic coast of the Florida peninsula. In the north part of the area, flow is from the southwest and northwest toward discharge areas and springs along the St. Johns River. East of the St. Johns River, some ground-water flow enters the area from the north. That lateral inflow, together, with locally recharged water moves either west toward the discharge areas and springs along the St. Johns River or to the east toward the Atlantic coast.

\section{DIGITAL COMPUTER MODEL}

The predevelopment flow system in the Floridan aquifer is investigated by means of a digital computer model in which the predevelopment steady-state flow system is simulated. Emphasis is placed on simulating the upper Floridan (1ayer 2) where most flow occurs.

The computer source code used in this report is adapted from the three-dimensional ground-water flow model developed by Trescott (1975) and Trescott and Larson (1976) and modified by Steven Larson and James Tracy (written commun., September 1979) to include the headcontrolled flux boundary condition. The model was further modified by the writer to facilitate data handling, error analysis, and output, and by Anthony Navoy, U.S. Geological Survey, Orlando, Fla., to include plotting of hydraulic cross-sections.

This computer model is used to simulate steady-state flow in the Floridan aquifer in the study area by computing the head response of the aquifer to the natural stresses of recharge and discharge. The model uses a finite-difference method to numerically solve partial differential equations that describe the ground-water flow in response to the stresses and boundary conditions.

Parts of the Floridan aquifer flow system in east-central Florida have previously been simulated by digital computer modeling; Grubb and Rutledge (1978) modeled the Green Swamp area in parts of Polk, Sumter, Lake, and Pasco Counties and Bush (1978) modeled central Volusia County. Both of these previous models were steady-state models and simulated the Floridan aquifer flow system as a single-layer system. 
The simulation described here is that of a three-layered system with each layer separated by a confining bed. In this model application, confining beds are not represented by layers. Rather, they are simulated only as "membranes" between aquifer layers and, herein, are referred to as "TK" layers. Vertical resistance to flow between aquifers is simulated by input of areally-variable leakance values to the TK layers in order to characterize the vertical hydraulic conductivity and thickness of the confining beds. No horizontal flow is simulated in the confining beds. Any appreciable horizontal hydraulic conductivity of the confining beds is reflected in the transmissivity values of the overlying and underlying aquifers.

The Floridan aquifer is represented by two aquifer layers overlain by a TK layer which is, in turn, overlain by a third layer, the surficial aquifer. The Floridan is assumed to be underlain by impermeable rocks. The layering of the Floridan is simulated by the inclusion of a TK layer between the aquifer layers (fig. 3, in pocket). In actuality, this intra-aquifer confining bed is merely a less permeable part of the Floridan.

The model area is subdivided into a finite-difference grid of 24 rows and 50 columns (fig. 5, in pocket). Each of the 1,200 grid blocks, or nodes, is 4 miles on a side or $16 \mathrm{mi}^{2}$ in area. Due to the configuration of the model boundaries there are only 857 active model nodes within the limits of the modeled area. This represents a surface area of about 13,700 $\mathrm{mi}^{2}$.

Various hydrologic properties of the aquifers and confining beds are input to each node within the modeled area. The types of hydrologic input data are summarized in table 1 , and will be discussed in more detail later in this report.

\section{Boundary Conditions}

The boundaries of the modeled area are defined by the configuration of the potentiometric surface of the upper part of the Floridan aquifer (fig. 4, in pocket), and the location of the landward extent of the aquifer system. Where possible, the model boundaries are placed perpendicular to the potentiometric contours or along ground-water divides. In those areas, under predevelopment steady-state conditions, there would be no flow across the boundary. The boundary conditions in those areas are designated within the model as "no-flow" boundaries. Where the potentiometric contours are approximately parallel to the model boundary, the boundary conditions are designated within the model as HCF (headcontrolled flux). This boundary condition option was incorporated into the model source code by Larson and Tracy (written commun., September 1979). The HCF boundary condition allows cross-boundary flow to occur that is proportional to the head difference across the boundary. The degree of proportionality (boundary leakance coefficient) and the head outside the boundary, are input items and can vary from node-to-node. The HCF boundary condition is also used to simulate point discharge from the Floridan aquifer at springs. 
Table 1.--Mode1 input data

\begin{tabular}{|c|c|c|}
\hline Hydrologic parameter & $\begin{array}{l}\text { Aquifer } \\
\text { layer }\end{array}$ & $\begin{array}{c}\text { TK layer } \\
\text { (confining bed) }\end{array}$ \\
\hline Head & $1,2,3$ & - \\
\hline Storage coefficient- & 3 & - \\
\hline Transmissivity & $1,2,3$ & - \\
\hline Leakance (or recharge) ${ }^{2 /}$ & (2) & 1,2 \\
\hline \multicolumn{3}{|l|}{$\begin{array}{l}\text { Head-controlled flux boundary } \\
\text { conditions: }\end{array}$} \\
\hline Boundary head & $1,2,3$ & - \\
\hline $\begin{array}{l}\text { Boundary leakance } \\
\text { coefficient }\end{array}$ & $1,2,3$ & - \\
\hline
\end{tabular}

1 The storage coefficient input for layer 3 is -1 which has no physical meaning except to instruct the computer model to treat layer 3 as a constant-head source bed.

2 Early calibration efforts were made using direct recharge to layer 2 rather than simulating recharge as leakance from layer 3. In those simulations, layer 3 and confining bed 2 were eliminated. 
The lower Floridan and its upper confining bed act as a leaky base for the upper Floridan. There are few hydrologic data available for the lower part of the Floridan aquifer except in the immediate Orlando vicinity. If, however, the lower Floridan were to be ignored in the model, the upper Floridan would be mistakenly treated as if it had an impermeable base. Hence, the lower Floridan must be simulated but its primary significance is that of a lower boundary condition for the upper Floridan. The lower Floridan is assigned no-flow boundaries around the entire perimeter of the modeled area. In those areas where the upper Floridan has "no-flow" boundaries, the assumption that the lower Floridan also has "no-flow" boundaries is valid because the upper and lower Floridan flow systems are probably very similar. In areas where there is lateral flow across the boundaries of the upper Floridan, the designation of "no-flow" boundaries for the lower Floridan is less valid. However, as will be shown later, the amounts of cross-boundary flow are relatively insignificant (most discharge from the aquifer system occurs as springflow and upward leakage in discharge areas) and, therefore, little overall error is introduced in terms of the model calibration of the upper Floridan.

The water table in the surficial aquifer is, in this steady-state simulation, considered to be at constant altitude. Therefore, all of the nodes in the modeled area of the surficial aquifer (layer 3) are assigned a constant-head boundary condition. The constant-head condition, in addition to holding a node's head constant, also allows the node to act as a hydraulic source or sink. The designation of constanthead for all nodes in the surficial aquifer (layer 3) allows that layer, and its underlying confining bed, to act as a source-sink leaky upper boundary for layer 2, the upper Floridan aquifer (layer 2). It allows inflow and outflow to or from the Floridan to be simulated as leakage occurring to or from the surficial aquifer through confining bed 2 without having to actually simulate hydraulic response in the surficial aquifer itself. This treatment of the surficial aquifer in the model is valid if the estimates of the predevelopment heads in the aquifer are reasonably accurate.

\section{Hydrogeologic Input Data}

Layer 2, the upper Floridan, is the primary focus of the modeling effort. Therefore, most of the following discussion on input data (table 1) will treat layer 2 first, followed by layer 1 (lower Floridan), and then layer 3 (surficial aquifer). Starting heads for layers 2 and 3 are the best "known" data even though that for layer 3 is only a rough estimate. The remainder of the data, except for a few transmissivity values determined by aquifer tests, are first arbitrarily assumed and then refined by trial and error during the calibration process. The calibration process consists of comparing computed heads for the upper Floridan against the starting heads and, also, comparing computed spring discharge against observed discharge of selected springs and adjusting the input parameters. The calibration process will be discussed in greater detail in a later section of this report. 


\section{Hydraulic Head}

The starting head for each node in layer 2 (upper Floridan aquifer) is obtained by superimposing the finite-difference grid (fig. 5, in pocket) on the potentiometric surface map for layer 2 (fig. 4, in pocket) and determining the average head for each node. There are no maps for layer 1. The few head data that exist for layer 1 suggest that, in recharge areas for layer 2, the head in layer 1 is a few feet lower than in layer 2. Conversely, in discharge areas for layer 2, the head in layer 1 tends to be a few feet higher than in layer 2. To determine the location of discharge areas, the finite-difference grid is placed over Healy's (1962) 1961 Floridan aquifer potentiometric map that also shows area of artesian flow (discharge areas). At nodes lying in discharge areas, the starting head in layer 1 is arbitrarily assigned a value that is 2 feet higher than that determined for layer 2 at that node location. At the remainder of the nodes, the starting head in layer 1 is assigned a value that is 2 feet lower than that for layer 2 .

Starting heads for layer 3 (surficial aquifer) are obtained by superimposing the finite-difference grid on U.S. Geological Survey topographic maps and, from the surface-water features and altitudes, estimating the altitude of the water table in the surficial aquifer.

\section{Storage Coefficient}

Because this model is a steady-state simulation, the effects of storage in the aquifer are not a consideration, hence the storage coefficient is zero in all nodes of layers 1 and 2 .

Layer 3 is simulated as a source-sink bed for the Floridan aquifer system and every node in layer 3 is made a constant-head node.

\section{Transmissivity}

The transmissivity of the upper Floridan (1ayer 2) varies throughout the model area. Figure 6 (in pocket) shows a comparison of field values for transmissivity derived from aquifer tests and transmissivity values obtained by trial and error during the calibration process. The average of model-derived transmissivity values for the upper Floridan is about $120,000 \mathrm{ft}^{2} / \mathrm{d}$; the maximum is $800,000 \mathrm{ft}^{2} / \mathrm{d}$ (in a node where there is a large spring); the minimum is $13,000 \mathrm{ft}^{2} / \mathrm{d}$. Note that the transmissivity values obtained by aquifer test analyses do not always agree with those required to calibrate the model. Generally, the modelderived transmissivities are higher than those obtained from aquifer tests. This is due in part to the fact that wells used in aquifer tests generally tap less than the full thickness of the aquifer. This partial penetration plus the highly heterogeneous and anisotropic nature of the cavernous limestone aquifer system make the application of standard 
methods of aquifer test analysis uncertain and the resulting transmissivity values questionable. For example, note that in east Orange County, there are three aquifer test sites located within the equivalent area of one model node (fig. 6 , in pocket), but the transmissivity values obtained are $74,000 \mathrm{ft}^{2} / \mathrm{d}, 210,000 \mathrm{ft}^{2} / \mathrm{d}$, and $510,000 \mathrm{ft}^{2} / \mathrm{d}$. Furthermore, counter to what would ordinarily be expected, the test that had the greatest penetration of aquifer thickness had the lowest transmissivity. The transmissivity range required for model calibration $\left(100,000\right.$ to $\left.200,000 \mathrm{ft}^{2} / \mathrm{d}\right)$ in the area of those three tests is considered to have more regional significance than the individual test values. The aquifer test data in figure 6 are used only as a rough guide for the assigning initial transmissivity values to the upper Floridan.

The transmissivity for layer 1 (lower Floridan aquifer) is obtained by trial and error during calibration just as in the case of layer 2 (upper Floridan aquifer). However, since the starting heads for layer 1 are, as previously discussed, arbitrarily assigned and the comparison of computed head versus starting head is what constitutes the calibration process, the model-derived values of transmissivity for the lower Floridan (layer 1) as shown in figure 7 (in pocket) are rough estimates. The average of transmissivity values used in layer 1 is $60,000 \mathrm{ft}^{2} / \mathrm{d}$; the maximum is $130,000 \mathrm{ft}^{2} / \mathrm{d}$; the minimum is $30,000 \mathrm{ft}^{2} / \mathrm{d}$.

Transmissivity of layer 3 (surficial aquifer) is, in this model, meaningless because layer 3 is treated as a source-sink layer for leakage to or from layer 2 through confining bed 2. Transmissivity must, however, be set at some nonzero value because of the model's computational process and thus, is arbitrarily set at $1,000 \mathrm{ft}^{2} / \mathrm{d}$.

\section{Leakance}

All vertical inflow to the upper Floridan (layer 2) is by way of leakage through confining bed 2 (TK layer 2) that separates the surficial aquifer (layer 3 ) from the upper Floridan.

The rate of flux through TK layer 2 varies from place to place according to its thickness and vertical hydraulic conductivity and the head difference between aquifer layers 2 and 3 . The leakance coefficient for TK layer 2 can be calculated as:

$$
\mathrm{L} 2=\frac{\mathrm{R} 2}{(\mathrm{H} 3-\mathrm{H} 2)} \quad \mathrm{T}^{-1}
$$

Where L2 is the leakance coefficient for TK layer 2, R2 is the recharge or leakage rate through TK layer 2, $\mathrm{H} 3$ is the head in layer 3 , and $\mathrm{H} 2$ is the head in layer 2. H3 and H2 are "known" or fixed input data whereas L2 is determined by trial and error. It is obvious from the above 
equation that the key unknown variable is R2. Therefore, between trialand-error model calibration runs, estimates of R2 were adjusted and new values of $\mathrm{L} 2$ were manually calculated and then input for the next model run. The final estimates of $\mathrm{R} 2$ are shown in figure 8 (in pocket).

The leakance coefficent, L1, of TK layer 1 (mid-Floridan confining bed 1) is, except for one node (row 13, col. 31), assumed to be uniform at $5 \times 10^{-5} \mathrm{~d}^{-1}$. This number is arbitrarily assumed but, as will be shown in the section on sensitivity analysis, the model calibration is relatively insensitive to changes in $\mathrm{L} 1$.

Vertical leakage at node $(13,31)$ in TK layer 1 is assumed to be very high because of the location of a geologic fault ( $J$. A. Miller, written commun., 1980). It is inferred that layers 1 and 2 are in very good hydraulic connection at that location.

\section{Head-Controlled Flux (HCF) Boundary Conditions}

As discussed previously, flow at model boundaries and at springs is simulated by a HCF boundary condition. Although the HCF boundary condition $c$ an be input to any node in any layer in the model, in this model they are applicable only to nodes in the upper Floridan (1ayer 2). The data that descibe the HCF boundary condition for layer 2 consist of three parameters; boundary head (HSS2), boundary leakance coefficient (CSS2), and starting head, H2. The equation that determines the crossboundary flux (QSS2) is:

$$
\mathrm{QSS} 2=\operatorname{CsS} 2(\mathrm{HSS} 2-\mathrm{H} 2) \mathrm{A} \quad \mathrm{L}^{3} \mathrm{~T}^{-1}
$$

$\mathrm{H} 2$ has been previously discussed as an input item. A is the surface area of the model node in which an HCF boundary condition is specified. In the case of lateral flow at the boundaries of the model, HSS 2 is the head at a point beyond the model boundary where it can be assumed that (1) the head in the upper Floridan will remain constant and (2) the head in the upper Floridan is about the same as the water table in the surficial aquifer. In the case of springs that discharge from the upper Floridan (1ayer 2), HSS2 is the head (or altitude) of the spring pool.

CSS2 is the boundary leakance coefficient determined by dividing the estimated cross-boundary flow, or in the case of a spring, the spring discharge by the head difference (HSS2-H2) across the boundary.

The locations of HCF boundary nodes and the flux at those nodes are shown in figure 4 (in pocket). 


\section{MODEL CALIBRATION}

The intent of this model application is to define and quantify the predevelopment ground-water flow system. The only stresses are those of naturally-occurring recharge and discharge. In carrying out the calibration, aquifer parameters are adjusted until the difference between the heads computed by the model and the predevelopment heads are minimized and until the spring discharges computed by the model are in approximate agreement with observed and estimated predevelopment spring discharges. The predevelopment head data for the upper Floridan are presumed reasonably accurate. Predevelopment heads for the lower Floridan and the surficial aquifer are rough estimates.

Calibration of this model generally consisted of adjusting the transmissivity (T2) of the upper Floridan aquifer (1ayer 2) and the leakance coefficient (L2) of the confining bed that overlies the upper Floridan. The leakance coefficient of (L1) of the mid-Floridan confining bed and the transmissivity (T1) of the lower Floridan were adjusted very early in the calibration process and then not changed during the remainder of the calibration. As will be shown in the sensitivity analysis section of this report, the model is relatively insensitive to adjustments in $\mathrm{L} 1$ and $\mathrm{T} 1$, but is very sensitive to adjustments in $\mathrm{L} 2$ and $\mathrm{T} 2$.

The calibration error of the model is shown by (1) the difference between the computed and observed head at each node in layers 2 and 1 (figs. 9 and 10, both in pocket) and, (2) the ability of the model to duplicate the measured flows at key springs that discharge from the upper Floridan (table 2). The average error in head is about 1.3 feet for the upper Floridan (layer 2) and about 3.3 feet for the lower Floridan (layer 1). (Note: The average error is the average of the absolute values of the head changes in all nodes during a model run.) The model was able to simulate total discharge of the key springs within 2 percent. These errors are well within the range of error for which the measured heads and spring discharge are known or can be determined. The close approximation of steady-state heads and spring discharge in the upper Floridan suggest that the model, as constructed, accurately simulates predevelopment conditions--at least in the upper Floridan.

Note that, in general, flows from the larger springs were simulated with least error (table 2). Errors up to 27 percent were obtained in simulating the smaller springs. This may be a problem of scale due to the model's inability to accurately simulate flow of small springs whose ground-water drainage basins comprise an area that is represented by only one or two model nodes. 
Table 2.--Flow of springs and at other head-controlled flux nodes in the upper Floridan aquifer (model layer 2)

\begin{tabular}{|c|c|c|c|c|c|c|}
\hline \multirow{2}{*}{\multicolumn{2}{|c|}{$\begin{array}{l}\text { Mode1 } \\
\text { node }\end{array}$}} & \multirow[b]{3}{*}{ Name or 1ocation } & \multicolumn{4}{|c|}{ F1ow $\left(\mathrm{ft}^{3} / \mathrm{s}\right)$} \\
\hline & & & \multicolumn{2}{|c|}{ Estimated } & \multirow[b]{2}{*}{ Computed } & \multirow{2}{*}{$\begin{array}{l}\text { Percent } \\
\text { error }\end{array}$} \\
\hline Row & Column & & observed- & & & \\
\hline 2 & 2 & West part of south boundary & - & & 6.5 & - \\
\hline 3 & 2 & do. & - & & 4.7 & - \\
\hline 4 & 2 & do. & - & & 1.9 & - \\
\hline 5 & 2 & do. & - & & 0.8 & - \\
\hline 5 & 31 & 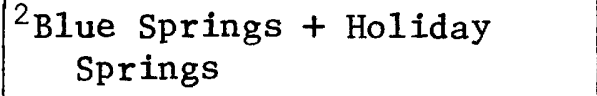 & $3+4=$ & 7 & 6.2 & -11.3 \\
\hline 6 & 2 & West part of south boundary & - & & 0.3 & - \\
\hline 6 & 27 & ${ }^{2}$ Apopka Spring & & 30 & 31.3 & $4 \cdot 3$ \\
\hline 8 & 42 & Oklawaha River & & (10) & 21.9 & - \\
\hline 8 & 43 & do. & & $(30)$ & 34.0 & - \\
\hline 8 & 44 & ${ }^{2}$ Orange Spring & & 8 & 8.7 & 8.8 \\
\hline 9 & 44 & Oklawaha River & & $(50)$ & 56.0 & - \\
\hline 10 & 28 & $\begin{array}{l}{ }^{2} \text { Wekiva Spring }+ \\
\quad \text { Witherington } \\
\quad \text { Spring + Miami Spring }\end{array}$ & $74+4+5=$ & 83 & 84.0 & 1.2 \\
\hline 10 & 29 & ${ }^{2}$ Rock Springs & & 65 & 65.4 & .6 \\
\hline 10 & 31 & $\begin{array}{l}{ }^{2} \text { Seminole Spring }+ \text { Messant } \\
\quad \text { Springs }\end{array}$ & $20+36=$ & 56 & 62.5 & 11.6 \\
\hline 10 & 33 & ${ }^{2}$ Camp La-No-Che Spring & & 1 & 0.8 & -20.0 \\
\hline 10 & 37 & $\begin{array}{c}{ }^{2} \text { Juniper Springs }+ \text { Fern } \\
\text { Hammock Springs }\end{array}$ & $16+16=$ & 32 & 27.7 & -13.4 \\
\hline 10 & 38 & 2Juniper Creek & & 70 & 76.1 & 8.7 \\
\hline 10 & 40 & ${ }^{2}$ Salt Springs & & 80 & 81.5 & 1.9 \\
\hline 10 & 43 & Oklawaha River & & $(50)$ & 45.8 & - \\
\hline 11 & 28 & $\begin{array}{l}{ }^{2} \text { Sanlando Springs }+ \text { Palm } \\
\text { Springs }+ \text { Starbuck } \\
\text { Spring }\end{array}$ & $19+10+17=$ & 46 & 46.7 & 1.5 \\
\hline 11 & 35 & $\begin{array}{l}{ }^{2} \text { Alexander Springs }+ \\
\text { Alexander Spring } \\
\text { Creek }\end{array}$ & $100+30=$ & 130 & 136 & 4.6 \\
\hline
\end{tabular}

${ }^{1}$ Numbers in parentheses are estimated discharge, others are observed. ${ }^{2}$ Key spring used to evaluate model calibration. 
Table 2.--Flow of springs and at other head-controlled flux nodes in the upper Floridan aquifer (model layer 2)--Continued

\begin{tabular}{|c|c|c|c|c|c|}
\hline \multirow{2}{*}{\multicolumn{2}{|c|}{$\begin{array}{l}\text { Model } \\
\text { node }\end{array}$}} & \multirow[b]{3}{*}{ Name or location } & \multicolumn{3}{|c|}{ Flow $\left(\mathrm{ft}^{3} / \mathrm{s}\right)$} \\
\hline & & & \multirow{2}{*}{$\begin{array}{l}\text { Estimated } \\
\text { or } \\
\text { ohserved- }\end{array}$} & \multirow[b]{2}{*}{ Computed } & \multirow{2}{*}{$\begin{array}{c}\text { Percent } \\
\text { error }\end{array}$} \\
\hline Row & Column & & & & \\
\hline 11 & 38 & ${ }^{2}$ Silver Glen Springs & 112 & 113 & .9 \\
\hline 11 & 42 & Oklawaha River & - & 20.2 & - \\
\hline 12 & 30 & Wekiva River & - & 5.3 & - \\
\hline 12 & 34 & Alexander Spring Creek & 30 & 30.7 & - \\
\hline 12 & 37 & Lake George & (7) & 9.5 & - \\
\hline 12 & 38 & do. & (7) & 7.3 & - \\
\hline 12 & 39 & do. & (7) & 8.6 & - \\
\hline 12 & 42 & Beecher Spring + other & $9+(?)=(?)$ & 32.1 & - \\
\hline 12 & 43 & Satsuma Spring + other & $2+(?)=(?)$ & 2.9 & - \\
\hline 13 & 27 & 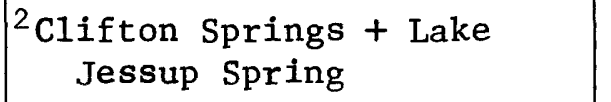 & $2+1=$ & 3.8 & 26.7 \\
\hline 13 & 30 & ${ }^{2}$ Gemini Spring & 8 & 7.2 & -10.0 \\
\hline 13 & 31 & ${ }^{2}$ Blue Spring & 160 & 157 & -1.9 \\
\hline 14 & 27 & Lake Jessup & - & 5.6 & - \\
\hline 14 & 35 & ${ }^{2}$ Ponce DeLeon Springs & 31 & 34.5 & 11.3 \\
\hline 15 & 28 & $\begin{array}{l}\text { St. Johns River below Lake } \\
\text { Harney }\end{array}$ & - & 8.9 & - \\
\hline 15 & 49 & East end of north boundary & - & 6.0 & - \\
\hline 16 & 27 & Lake Harney & - & 24.7 & - \\
\hline 16 & 28 & do. & - & 20.2 & - \\
\hline 16 & 48 & $\begin{array}{l}\text { East part of north } \\
\text { boundary }\end{array}$ & - & -1.2 & - \\
\hline 17 & 48 & do. & - & -3.6 & - \\
\hline 18 & 48 & do. & - & $-4 \cdot 2$ & \\
\hline 19 & 48 & do. & - & -4.7 & - \\
\hline 20 & 2 & South part of east boundary & - & 0.9 & - \\
\hline 20 & 3 & do. & - & 1.0 & - \\
\hline
\end{tabular}

${ }^{1}$ Numbers in parentheses are estimated discharge, others are observed. ${ }^{2}$ Key spring used to evaluate model calibration. 
Table 2.--Flow of springs and at other head-controlled flux nodes in the upper Floridan aquifer (model layer 2)--Continued

\begin{tabular}{|c|c|c|c|c|c|}
\hline \multirow{2}{*}{\multicolumn{2}{|c|}{$\begin{array}{l}\text { Mode1 } \\
\text { node }\end{array}$}} & \multirow[b]{3}{*}{ Name or location } & \multicolumn{3}{|c|}{ Flow $\left(\mathrm{ft}^{3} / \mathrm{s}\right)$} \\
\hline & & & \multirow{2}{*}{$\begin{array}{c}\text { Estimated } \\
\text { or } \\
\text { observed } 1 /\end{array}$} & \multirow[b]{2}{*}{ Computed } & \multirow{2}{*}{$\begin{array}{l}\text { Percent } \\
\text { error }\end{array}$} \\
\hline Row & Column & & & & \\
\hline 20 & 4 & South part of east boundary & - & 1.0 & - \\
\hline 20 & 5 & do. & - & 1.0 & - \\
\hline 20 & 6 & do. & - & 1.0 & - \\
\hline 20 & 7 & do. & - & 1.0 & - \\
\hline 20 & 8 & do. & - & 1.0 & - \\
\hline 20 & 9 & do. & - & 1.0 & - \\
\hline 20 & 10 & do. & - & 1.0 & - \\
\hline 20 & 11 & do. & - & 0.9 & - \\
\hline 20 & 29 & $\begin{array}{l}\text { Middle part of east } \\
\text { boundary }\end{array}$ & - & 6.3 & - \\
\hline 20 & 30 & do. & - & 5.6 & - \\
\hline 20 & 31 & do. & - & 5.6 & - \\
\hline 20 & 32 & do. & - & 5.5 & - \\
\hline 20 & 33 & do. & - & 6.2 & - \\
\hline 20 & 34 & do. & - & 6.7 & - \\
\hline 20 & 35 & do. & - & 5.9 & - \\
\hline 20 & 36 & do. & - & 3.7 & - \\
\hline 20 & 37 & do. & - & 2.6 & - \\
\hline 20 & 38 & do. & - & 2.2 & - \\
\hline 20 & 39 & do. & - & 0.7 & - \\
\hline 20 & 40 & do. & - & -0.6 & - \\
\hline 20 & 48 & $\begin{array}{l}\text { East part of north } \\
\text { boundary }\end{array}$ & - & -4.8 & - \\
\hline 21 & 12 & $\begin{array}{l}\text { South part of east } \\
\text { boundary }\end{array}$ & - & -0.4 & - \\
\hline 22 & 13 & do. & - & -0.5 & - \\
\hline 23 & 14 & do. & - & -0.7 & - \\
\hline
\end{tabular}

${ }^{1}$ Numbers in parentheses are estimated discharge, others are observed. 
Table 2.--Flow of springs and at other head-controlled flux nodes in the upper Floridan aquifer (model layer 2)--Continued

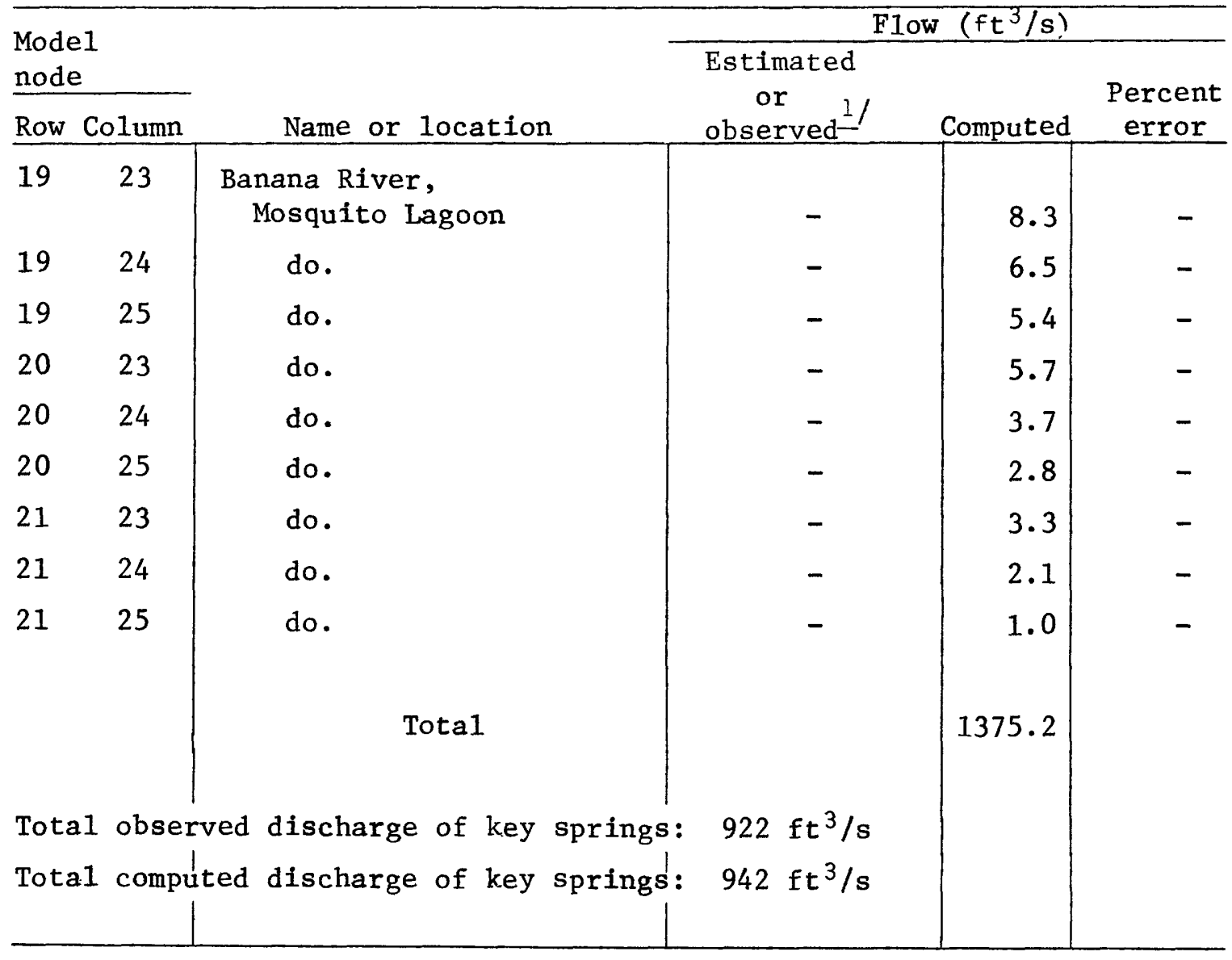

${ }^{l}$ Numbers in parentheses are estimated discharges, others are observed. 
There is some degree of uncertainty or error in all of the model hydrologic input parameter (table 1). The parameters of potentiometric head and spring discharge are considered "known" variables and are the basis upon which calibration is evaluated. The "unknown" variables are aquifer transmissivity and confining bed leakance.

The purpose of this parameter sensitivity analysis is to determine to what degree model calibration is affected by errors in transmissivity of the upper and lower Floridan and in leakance coefficient for confining beds 1 and 2 . Transmissivity of the surficial aquifer (layer 3 ) cannot be evaluated because the head in layer 3 is held constant.

A simple method of model sensitivity analysis is to uniformly vary an unknown variable, run the model, and observe the change in average head error per node and change in springflow error (computed minus observed key spring discharge). Table 3 shows the results of nine model runs where the transmissivity of the upper and lower Floridan and coefficients of the overlying and mid-Floridan confining beds were each raised and lowered by a factor of 2 . In addition, the leakance coefficient of the mid-Floridan confining bed was also raised by a factor of 4. The results of this analysis show that average error per node and computed key spring discharge are very sensitive to changes in leakance coefficient of the confining bed overlying the upper Floridan and to changes in transmissivity of the upper Floridan. The model calibration is comparatively insensitive to changes in leakance coefficient of the mid-Floridan confining bed and to changes in transmissivity of the lower Floridan. Thus, the fact that neither of those hydraulic parameters is known with any degree of certainty was not detrimental to achieving model calibration.

\section{SUMMARY OF THE PREDEVELOPMENT FLOW SYSTEM}

The predevelopment steady-state ground-water flow system for the Tertiary limestone (Floridan) aquifer in east-central Florida is simulated by means of a digital computer model. The ability of the calibrated model to closely approximate predevelopment heads and spring discharges in the upper Floridan indicate that the model is accurately simulating the flow system in that layer.

The modeled area covers about $13,700 \mathrm{mi}^{2}$. The configuration of the model is that of a three-layered system; the lower Floridan aquifer, the upper Floridan aquifer, and the surficial aquifer. The confining beds that separate the aquifer layers are simulated by TK layers that allow leakage to occur between aquifer layers in response to head differences between layers. Layer 1 (lower Floridan aquifer) is modeled as having no-flow lateral boundaries and an impermeable base. This means that all 
Table 3.--Effect of varying transmissivity and leakance on average error on key spring discharge

\begin{tabular}{|c|c|c|c|c|}
\hline \multirow{2}{*}{$\begin{array}{l}\text { Factor by which } \\
\text { input data were } \\
\text { varied }\end{array}$} & \multicolumn{2}{|c|}{ \pm Average error per node $(\mathrm{ft})$} & \multicolumn{2}{|c|}{$\begin{array}{l}\text { Computed minus } \\
\text { observed key } \\
\text { spring discharge } \mathrm{I}^{\text {l/ }}\end{array}$} \\
\hline & $\begin{array}{l}\text { Lower Floridan } \\
\text { aquifer (layer 1) }\end{array}$ & $\begin{array}{l}\text { Upper Floridan } \\
\text { aquifer (1ayer 2) }\end{array}$ & $\left(\mathrm{ft}^{3} / \mathrm{s}\right)$ & $\begin{array}{c}\text { Percent } \\
\text { difference }\end{array}$ \\
\hline $\begin{aligned} & 1.0 \\
& \text { (calibrated model } \\
&- \text { no change) }\end{aligned}$ & 3.31 & 1.33 & 20 & 2 \\
\hline $2.0 \times \mathrm{L} 2$ & 3.80 & 2.80 & 177 & 19 \\
\hline $0.5 \times \mathrm{L} 2$ & 4.06 & 2.76 & -154 & -17 \\
\hline $2.0 \times \mathrm{T} 2$ & 3.78 & 2.39 & 297 & 32 \\
\hline $0.5 \times \mathrm{T} 2$ & 3.43 & 2.09 & -205 & -22 \\
\hline $2.0 \times \mathrm{L} 1$ & 2.80 & 1.36 & 28 & 3 \\
\hline $4.0 \times \mathrm{L} 1$ & 2.50 & 1.40 & 38 & 4 \\
\hline $0.5 \times \mathrm{L} 1$ & 4.17 & 1.32 & 13 & 1 \\
\hline $2.0 \times \mathrm{T} 1$ & 4.40 & 1.64 & 50 & 5 \\
\hline $0.5 \mathrm{X} \mathrm{T1}$ & 2.80 & 1.40 & 3 & 0 \\
\hline
\end{tabular}

L1 - Leakance coefficient of TK layer 1 (confining bed 1) between aquifer L2 - Leakance coefficient of TK layer 2 (confining bed 2) between aquifer

T1 - Transmissivity of layer 1 .

T2 - Transmissivity of layer 2.

1 See table 2 for listing of key springs.

2 Includes all measured Floridan aquifer springs and other estimated Floridan aquifer spring discharge. 
per node for the upper and lower Floridan aquifer (layers 1 and 2) and model boundary flows

\begin{tabular}{|c|c|c|c|c|}
\hline \multicolumn{5}{|c|}{ Mode1-computed flows for upper Floridan (1ayer 2) } \\
\hline $\begin{array}{l}\text { Downward leakage } \\
\text { from layer } 3 \\
\text { to layer } 2 \\
\left(\mathrm{ft}^{3} / \mathrm{s}\right)\end{array}$ & $\begin{array}{l}\text { Boundary } \\
\frac{\text { inf low }}{\left(\mathrm{ft}^{3} / \mathrm{s}\right)}\end{array}$ & $\begin{array}{l}\text { Upward leakage } \\
\text { to layer } 3 \\
\text { from layer } 2 \\
\frac{\left(\mathrm{ft}^{3} / \mathrm{s}\right)}{}\end{array}$ & $\begin{array}{l}\text { Boundary } \\
\text { outf1ow } \\
\left(\mathrm{ft} \mathrm{t}^{3} / \mathrm{s}\right)\end{array}$ & $\begin{array}{l}\text { Total discharge } \\
\frac{\text { of springs }}{\left(\mathrm{ft}^{3} / \mathrm{s}\right)}\end{array}$ \\
\hline 1918 & 21 & 543 & 81 & 1315 \\
\hline 2481 & 39 & 973 & 64 & 1483 \\
\hline 1464 & 16 & 278 & 91 & 1111 \\
\hline 2449 & 20 & 634 & 138 & 1697 \\
\hline 1508 & 22 & 475 & 47 & 1008 \\
\hline 1953 & 21 & 556 & 85 & 1333 \\
\hline 1985 & 22 & 566 & 88 & 1353 \\
\hline 1883 & 20 & 528 & 76 & 1299 \\
\hline 2004 & 19 & 567 & 96 & 1360 \\
\hline 1856 & 22 & 521 & 71 & 1286 \\
\hline
\end{tabular}

layers 1 and 2 .

layers 2 and 3. 
inflow to or outflow from layer 1 must ultimately flow from and return to layer 2. Therefore, in this model, there is no net exchange of water between the two aquifer layers. A summary of ground-water flow is given in table 4 .

Though three aquifer layers are simulated, only the upper Floridan aquifer layer is considered calibrated. The overlying surficial aquifer is treated as a constant-head (though areally variable) source-sink layer for leakage between the surficial and upper Floridan aquifers. The lower Floridan aquifer flow system is simulated but the actual calibration of that layer is problematical because the starting heads were assumed and therefore provide no basis upon which to determine the degree of calibration.

As mentioned previously, all water that leaks upward from the lower Floridan to the upper Floridan must ultimately be derived from downward leakage from the upper Floridan. The upper Floridan aquifer (1ayer 2) in the modeled area is recharged by downward leakage from the surficial aquifer (layer 3), by lateral inflow at the northeast model boundary and by upward leakage from the lower Floridan (layer 1).

Model results indicate that about $1,900 \mathrm{ft}^{3} / \mathrm{s}(1.90 \mathrm{in} / \mathrm{yr})$ is recharged to the Floridan by downward leakage from the surficial aquifer. The average recharge rate in the approximately $6,550 \mathrm{mi}^{2}$ that are recharge areas (fig. 8, in pocket) is about $4 \mathrm{in} / \mathrm{yr}$. The maximum rate is about $14 \mathrm{in} / \mathrm{yr}$ and occurs in southeast Marion County. The recharge areas that have the lowest rates of downward leakage are in southeast Orange County, southeast Volusia County, most of northeast Okeechobee County, and the north-south lengths of the central portions of Osceola, St. Johns, and Flagler Counties. In those areas, recharge rates are generally $1 \mathrm{in} / \mathrm{yr}$ or less.

Recharge to the upper Floridan occurring as lateral boundary inflow is computed to be about $20 \mathrm{ft}^{3} / \mathrm{s}(0.02 \mathrm{in} / \mathrm{yr})$.

The lower Floridan aquifer recharges the upper Floridan at a rate of about $290 \mathrm{ft}^{3} / \mathrm{s}(0.29 \mathrm{in} / \mathrm{yr})$. The average rate of recharge in all recharging nodes except that of row 13, column 31 is about $0.6 \mathrm{in} / \mathrm{yr}$. The maximum rate for those nodes is about $3 \mathrm{in} / \mathrm{yr}$.

At node 13,31 (the location of Blue Springs) the upper Floridan is recharged by the lower Floridan at the rate of about $35 \mathrm{in} / \mathrm{yr}$ (41 $\left.\mathrm{ft}^{3} / \mathrm{s}\right)$. The leakance coefficient at that node was set very high to hydraulically simulate a geologic fault that provides very good hydraulic connection between the upper and lower Floridan.

The upper Floridan aquifer, under predevelopment conditions, discharges water by springs, by diffuse downward leakage to the lower Floridan locally, by diffuse upward leakage to the surficial aquifer in discharge areas, and by lateral outflow at the model boundaries. Total 
Table 4.--Summary of ground-water

\begin{tabular}{|c|c|c|c|c|c|c|}
\hline \multirow[b]{2}{*}{ Layer } & \multicolumn{6}{|c|}{ Recharge } \\
\hline & $\begin{array}{l}\text { from la } \\
\left(\mathrm{ft}^{3} / \mathrm{s}\right)\end{array}$ & $\begin{array}{c}\text { er above } \\
\text { (in/yr) }\end{array}$ & $\begin{array}{l}\text { from } 1 \\
\left(\mathrm{ft}^{3} / \mathrm{s}\right)\end{array}$ & $\begin{array}{l}\text { r below } \\
\text { (in/yr) }\end{array}$ & $\left(\mathrm{ft}^{3 / \mathrm{s}}\right)^{1 \mathrm{a}}$ & $\begin{array}{l}\mathrm{ral} \\
\text { (in/yr) }\end{array}$ \\
\hline $\begin{array}{l}3 \\
\text { (surficial } \\
\text { aquifer) }\end{array}$ & $1 /$ & - & 543 & 0.54 & 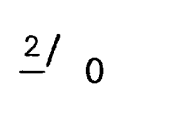 & 0 \\
\hline $\begin{array}{l}2 \\
\text { (upper } \\
\text { Floridan } \\
\text { aquifer) }\end{array}$ & 1918 & 1.90 & 290 & 0.29 & 21 & 0.02 \\
\hline $\begin{array}{c}1 \\
\text { (lower } \\
\text { Floridan } \\
\text { aquifer) }\end{array}$ & 290 & 0.29 & $3 /-$ & - & $2 / 0$ & 0 \\
\hline
\end{tabular}

1 Layer 3 is uppermost layer (surficial aquifer) and is simulated as a constant-head source-sink layer.

2 No-flow lateral boundary conditions.

3 No recharge from below because base of layer 1 is simulated as impermeable. 
flow computed by mode1

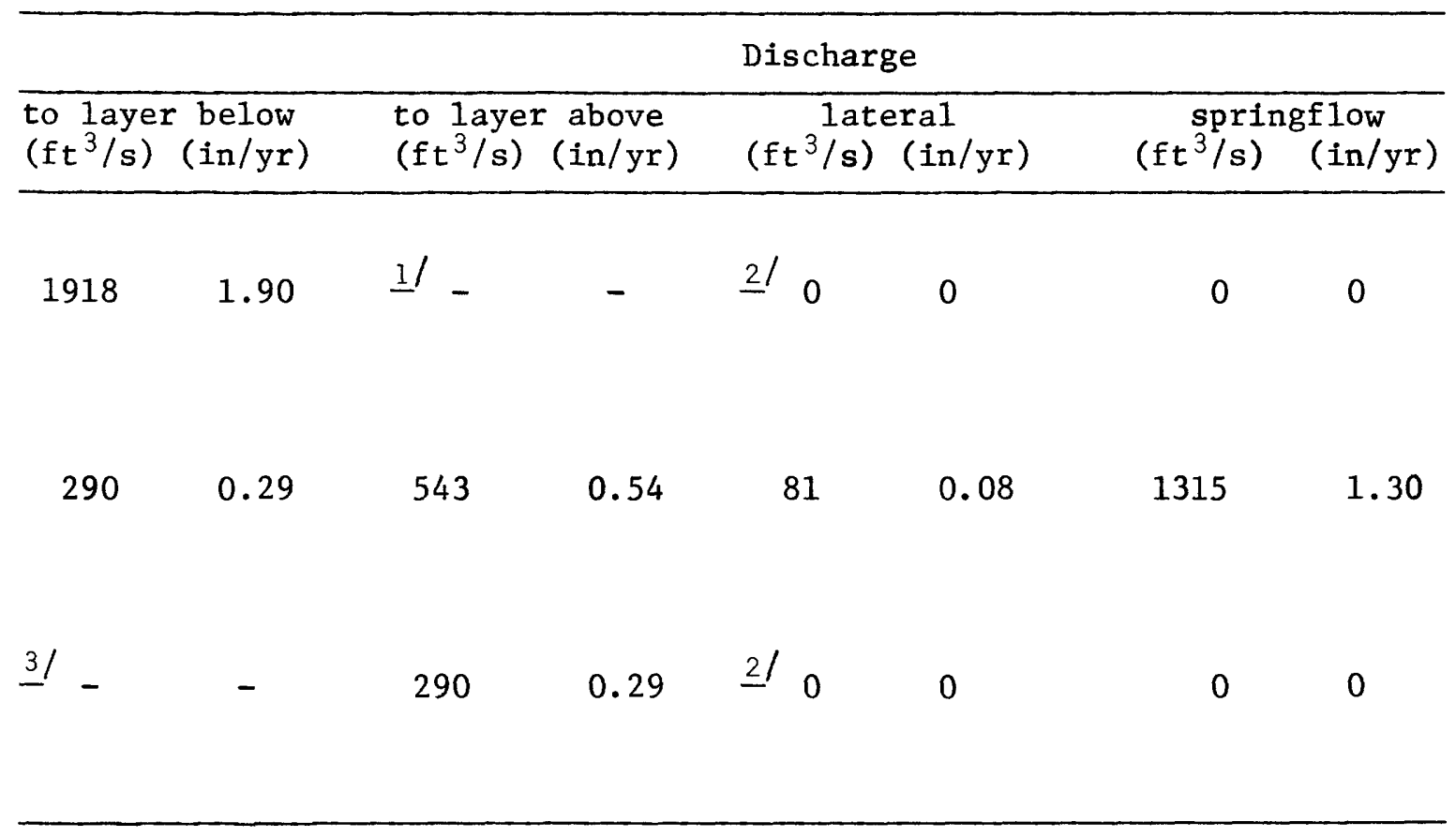


simulated springflow is about $1,300 \mathrm{ft}^{3} / \mathrm{s}$ and consists of about $940 \mathrm{ft}^{3} / \mathrm{s}$ discharge from known springs (key springs) for which some discharge data are available; about $180 \mathrm{ft}^{3} / \mathrm{s}$ discharge into rivers where Floridan springflow has been indirectly determined by means of streamflow and water-quality measurements that indicate that Floridan aquifer water is being contributed in large quantities; and about $190 \mathrm{ft}^{3} / \mathrm{s}$ discharge estimated to occur in areas where depressions in the potentiometric surface of the Floridan strongly suggest that spring discharge is occurring.

The model results indicate that the upper Floridan discharges about $540 \mathrm{ft}^{3} / \mathrm{s}(0.54 \mathrm{in} / \mathrm{yr})$ as diffuse upward leakage to the surficial aquifer. The average discharge rate in the approximately $7,150 \mathrm{mi}^{2}$ that are discharge areas (fig. 8 , in pocket) is about $1 \mathrm{in} / \mathrm{yr}$. The maximum computed rate is 6 in/yr and occurs in the vicinity of Lake Kissimmee in west 0sceola County. The lowest rates of discharge occur in south Brevard County, Indian River County, and north St. Lucie County. In those areas, discharge rates are generally $0.5 \mathrm{in} / \mathrm{yr}$ or less.

The lateral discharge at the model boundaries of the upper Floridan (layer 2) is about $80 \mathrm{ft}^{3} / \mathrm{s}(0.08 \mathrm{in} / \mathrm{yr})$ and occurs along the east and southwest model boundaries.

The average transmissivity of layer 2 is about $120,000 \mathrm{ft}^{2} / \mathrm{s}$; the maximum is $800,000 \mathrm{ft}^{2} / \mathrm{d}$ (in a node where there is a large spring); the minimum is $13,000 \mathrm{ft}^{2} / \mathrm{d}$. The average transmissivity of layer 1 is $60,000 \mathrm{ft}^{2} / \mathrm{d}$; the maximum is $130,000 \mathrm{ft}^{2} / \mathrm{d}$; the minimum is $30,000 \mathrm{ft}^{2} / \mathrm{d}$.

Based on the model, the essential features of the predevelopment flow system are described as follows:

1. The highest rates of recharge to the Floridan are in four areas: the west flank of the Volusia County "high"; the Putnam-Alachua County "high"; the potentiometric ridge area of mid-Polk and Highlands Counties; and the northeast flank of the central Florida potentiometric "high" in Lake and Orange Counties and extending into east Marion County.

2. Most discharge from the upper Floridan is in the form of point discharge (about 69 percent of the total) to springs and streams located within 25 miles of recharge areas.

3. The highest rates of diffuse upward leakage from the upper Floridan (about 28 percent of total discharge) occur near areas where the downward leakage rates are also high. Thus, it is inferred that thin or permeable confining beds are common to the areas of high upward leakage and to the nearby areas of high downward leakage.

4. Lateral boundary outflow from the upper Floridan aquifer (principally occurring along the Atlantic coast) is relatively small and consists of about 4 percent of total discharge. Lateral flow to the south is about 0.7 percent of the total discharge. 
5. Interchange between the upper and lower Floridan aquifer layers is relatively small compared to the flow within the upper Floridan.

6. The model-derived transmissivities are considered to have more regional significance than transmissivity values derived from individual aquifer tests.

In summary, the hydraulics of the Tertiary limestone (Floridan) aquifer system under predevelopment conditions involve mostly recharge to the upper Floridan (by way of leakage from the surficial aquifer), lateral movement through the upper Floridan for short distances, and discharge by way of springs and stream seepage. Relatively small amounts of discharge occur along the coast and small amounts move into and out of the underlying lower Floridan. This natural hydraulic equilibrium implies a vigorous flow system locally in the upper Floridan and, except in west Orange County and southeast Lake County, a relatively sluggish flow system in the lower Floridan. 


\section{REFERENCES}

Applin, P. L., and Applin, E. R., 1944, Regional subsurface stratigraphy and structure of Florida and southern Georgia: American Association of Petroleum Geologists Bulletin, vo1. 28, no. 12, p. 1673-1753.

Bush, P. W., 1978, Hydrologic evaluation of part of central Volusia County, Florida: U.S. Geological Survey Water-Resources Investigations $78-89,50 \mathrm{p}$.

Cooke, C. W., 1939, Scenery of Florida interpreted by a geologist: Florida Geological Survey Bulletin 17, 118 p.

1945, Geology of Florida: Florida Geological Survey Bulletin 29, $342 \mathrm{p}$.

Faulkner, G. L., 1973, Geohydrology of the Cross-Florida Barge Canal area with special reference to the Ocala vicinity: U.S. Geological Survey Water-Resources Investigations 1-73, $117 \mathrm{p}$.

Grubb, H. G., and Rutledge, A. T., 1978, Long-term water supply potential, Green Swamp area, Florida: U.S. Geological Survey Water-Resources Investigations 78-99, $76 \mathrm{p}$.

Healy, H. G., 1962, Piezometric surface and areas of artesian flow of the Floridan aquifer in Florida, July 6-17, 1962: Florida Board of Conservation, Division of Geology, Map Series No. 4.

Johnston, R. H., Krause, R. E., Meyer, R. W., Ryder, P. D., Tibbals, C. H., and Hunn, J. D., 1980, Estimated potentiometric surface for the Tertiary limestone aquifer system, southeastern United States, prior to development: U.S. Geological Survey Open-File Report 80-406.

Lichtler, W. F., 1972, Appraisal of water resources in the east central Florida region: Florida Bureau of Geology Report of Investigations No. $61,52 \mathrm{p}$.

Matson, G. C., and Sanford, Samue1, 1913, Geology and ground waters of Florida: U.S. Geological Survey Water-Supply Paper 319, 445 p.

Miller, J. A., 1981, Geology and configuration of the top of the Tertiary limestone aquifer system, southeastern United States: U.S. Geological Survey Water-Resources Investigations Open-File Report 81-1178 (in press).

National Oceanographic and Atmospheric Administration, C1imatological data, Florida, annual summaries.

Puri, H. S., and Vernon, R. 0., 1959, Summary of the geology of Florida and a guide to the classic exposures: Florida Geological Survey Special Publication 5, 255 p. 
Stringfield, V. T., 1966, Artesian water in Tertiary limestone in the southeastern states: U.S. Geological Survey Professional Paper 517, $226 \mathrm{p}$.

Trescott, P. C., 1975, Documentation of finite-difference model for simulation of three-dimensional ground-water flow: U.S. Geological Survey Open-File Report 75-438, 99 p.

Trescott, P. C., and Larson, S. P., 1976, Supplement to Open-File Report 75-438, Documentation of finite-difference model for simulation of three-dimensional ground-water flow, U.S. Geological Survey Open-File Report 76-591, 21 p.

Vernon, R. 0., 1951, Geology of Citrus and Levy Counties, Florida: Florida Geological Survey Bulletin 33, 256 p.

1959, Surface occurrences of geologic formations in Florida: Florida Geological Survey Biennial Report 13, 84 p.

White, W. A., 1958, Some geomorphic features of central peninsular Florida: Florida Geological Survey Bulletin 41, 92 p.

1970, The geomorphology of the Florida peninsular: Florida Bureau of Geology Bulletin 51, $164 \mathrm{p}$. 


